\title{
Effects of green tea consumption on glycemic control: a systematic review and meta-analysis of randomized controlled trials
}

\author{
Renfan Xu' ${ }^{1}$ Yang Bai $^{2}$, Ke Yang ${ }^{2}$ and Guangzhi Chen ${ }^{2^{*}}$ (i)
}

\begin{abstract}
Background: The results of human clinical trials investigating the effects of green tea on glycemic control are inconsistent.

Methods: We conducted a systematic review and meta-analysis of RCTs that examined the effects of green tea supplementation on glycemic control. A literature search in PubMed, Embase, and Cochrane Library databases for RCTs that investigated the effect of green tea consumption on glycemic control was performed up to February 2020. A random-effects model was used to estimate weighted mean difference (WMD) with 95\% confidence intervals (Cls).

Results: Twenty-seven trials involving 2194 subjects were included in the meta-analysis. The pooled results showed that green tea significantly lowered fasting blood glucose by $-1.44 \mathrm{mg} / \mathrm{dL}(95 \% \mathrm{Cl}:-2.26,-0.62 \mathrm{mg} / \mathrm{dL} ; P<0.001)$ with no obvious heterogeneity $\left(P^{2}=7.7 \%\right)$. However, green tea consumption did not significantly affect fasting insulin and $\mathrm{HbA1c}$ values. The mean differences were $-0.46 \mu \mathrm{lU} / \mathrm{mL}(95 \% \mathrm{Cl}:-1.10,0.17 \mu \mathrm{lU} / \mathrm{mL} ; P=0.21)$ for fasting insulin and $-0.06 \%$; $(95 \% \mathrm{Cl}:-0.12,0.01 \% ; P=0.07)$ for $\mathrm{HbA}_{1 \mathrm{c}}$ concentrations. Heterogeneity was significant in fasting insulin $\left(P^{2}=46.8 \%\right)$ and mild in $\mathrm{HbA}_{1 c}\left(P^{2}=1.7 \%\right)$.

Conclusions: In short-term trials, green tea supplementation significantly reduced fasting glucose, but had no significant effect on fasting insulin and $\mathrm{HbA}_{1 \mathrm{c}}$. Long-term trials assessing the effects of green tea supplementation on glycemic control are needed.
\end{abstract}

Keywords: Green tea, Catechin, Glycemic control, Meta-analysis

\section{Introduction}

Type 2 diabetes mellitus (T2DM) is a significant global public health challenge [1]. By the end of 2017, more than 451 million people were living with T2DM worldwide. Moreover, this number is projected to rise to 693 million

\footnotetext{
* Correspondence: chengz2003@163.com

${ }^{2}$ Division of Cardiology, Department of Internal Medicine, Tongji Hospital, Tongji Medical College, Huazhong University of Science and Technology, Wuhan 430030, P.R. China

Full list of author information is available at the end of the article
}

by 2045 [2]. T2DM is one of the leading risk factors for premature mortality [3]. In addition, T2DM is associated with adverse health outcomes including heart attack, stroke, blindness, kidney failure, and amputation [4]. In prediabetic individuals with impaired glucose tolerance or fasting glucose, lifestyle modification can decelerate the progression to T2DM [3] . However, it is difficult to achieve and sustain sufficient lifestyle intervention. Although medications may play a role in delaying the onset of diabetes, long-term usage may be costly and associated

C C The Author(s). 2020 Open Access This article is licensed under a Creative Commons Attribution 4.0 International License, which permits use, sharing, adaptation, distribution and reproduction in any medium or format, as long as you give appropriate credit to the original author(s) and the source, provide a link to the Creative Commons licence, and indicate if changes were made. The images or other third party material in this article are included in the article's Creative Commons licence, unless indicated otherwise in a credit line to the material. If material is not included in the article's Creative Commons licence and your intended use is not permitted by statutory regulation or exceeds the permitted use, you will need to obtain permission directly from the copyright holder. To view a copy of this licence, visit http://creativecommons.org/licenses/by/4.0/ The Creative Commons Public Domain Dedication waiver (http://creativecommons.org/publicdomain/zero/1.0/) applies to the data made available in this article, unless otherwise stated in a credit line to the data. 
with various side effects. Plants have always been an important source of drugs, and many currently available drugs were either directly or indirectly derived from plants [5]. Herbal drugs are widely used for their effectiveness, relatively low cost, and fewer side effects.

Green tea is produced from the fresh leaves of Camellia sinensis and has played an important dietary and medicinal role throughout history, particularly in Asian countries. Green tea contains a variety of effective compounds including antioxidants, vitamins, carbohydrates, protein, minerals, and flavonoid-like polyphenols [6], which may be beneficial in the prevention of diabetes. The most prominent effects of green tea on human health are mainly attributed to catechins, which belong to the flavonoid-like polyphenols family. The four major catechins found in green tea extract are epicatechin (EC), epigallocatechin (EGC), epicatechingallate (ECG), and epigallocatechingallate (EGCG) [7].

A previous meta-analysis with 17 randomized controlled trials (RCTs) suggested that green tea consumption resulted in a significant reduction in fasting blood glucose (FBG) and glycated hemoglobin $\left(\mathrm{HbA}_{1 \mathrm{c}}\right)$ [8]. In addition, a meta-analysis with 9 cohort studies showed that green tea consumption was associated with a significant reduction of T2DM risk [9]. Both in vitro and animal experiments have shown that green tea catechins, especially EGCG can significant improve glycemic control as well as insulin sensitivity and may lower insulin requirement $[10,11]$. However, findings from randomized controlled trials (RCTs) on green tea supplementation and glycemic control or insulin sensitivity in individuals with preclinical diabetes or T2DM are debatable. Some studies observed that green tea significantly improve glycemic control [12], whereas others found no significant association between green tea intake and glycemic control $[13,14]$.

Given the inconsistency of prior clinical studies and the limitations in these previous meta-analyses, such as the inadequate consideration of possible confounding factors and lower number of included references, we performed a systematic review and meta-analysis to update the evidence which quantitatively assess the effect of green tea supplementation on measures of glucose control and insulin sensitivity.

\section{Methods}

\section{Search strategy and eligibility criteria}

This systematic review and meta-analysis was conducted in accordance with the recommendations outlined in the PRISMA (Preferred Reporting Items for Systematic Reviews and Meta-Analyses) statement [15]. Relevant English-language articles were identified via searches in PubMed, Embase, and the Cochrane Library from the index date of each database through February 2020. The search terms were as follows: "green tea," "green tea extract," "tea component(s)," "tea solid(s)," "tea polyphenols," "catechin," "catechins," "EGCG," and "Camellia sinensis," which were paired with the following words: "glucose," "glyc(a)emia," "hyperglycaemia," "glucose control," "insulin," "insulin sensitivity," "insulin resistance," "HbA $1 \mathrm{c}$," "glycated protein," "fructosamine," and "diabetes". Additional studies were identified by manually screening the reference of originally identified reviews and research reports or the clinical trials. The search was confined to studies involving humans.

\section{Study selection}

The prespecified inclusion criteria were as follows: 1) RCTs with both parallel and crossover interventions, 2) study involved adult subjects who consumed green tea for $\geq 2$ weeks, 3) blood glucose was evaluated by estimating the concentrations of FBG, fasting blood insulin (FBI) and $\mathrm{HbA}_{1 \mathrm{c}}$, and 4) the study used a concurrent control group with the only difference between the treatment and control groups being the consumption of either green tea or green tea extract. The exclusion criteria were as follows: 1 ) subjects in each group $\leq 10,2$ ) green tea extract was given as part of a multicomponent supplement,3) RCTs that did not report mean (SD) changes in fasting glucose, fasting insulin, or $\mathrm{HbA}_{1 \mathrm{c}}$ in each treatment group and could not be calculated from the data available. The data from multiple published reports involving the same study population were included only once.

\section{Quality assessment}

Two review authors (CGZ and XRF) independently assessed the study quality and any disagreement was resolved by discussion between the third author (YK). Jadad scoring criteria was used in which a study was judged on $0-5$ points (5 reflected the highest quality). With this system, one point was allocated to each for 1) randomization; 2) double blinding (participant and researcher masking); 3) reporting the number of and reasons for withdrawal; 4) generation of random numbers; and 5) allocation concealment. Trials were considered of high-quality if the Jadad score was $\geq 4$, while trials were classified as low-quality if the Jadad score was $<4$ [16].

\section{Data extraction}

Two authors (CGZ and XRF) independently extracted the data, and any discrepancies between the two reviewers were resolved through discussion with a third author (BY). The following information was recorded using a standardized electronic form: study characteristics (the first author, publication year, study design, study duration, sample size, intervention type, and dosage), population information (age, sex, country, and 
baseline fasting glucose), and baseline and final concentrations or net changes of FBG, FBI, HbA1c and homeostatic model assessment of insulin resistance (HOMAIR). Studies with multiple dosages of green tea or multiple control groups were included separately in the meta-analysis.

\section{Statistical analysis}

A meta-analysis was performed with the use of the STATA statistical software (version 11; STATA Corp LP). For parallel trials, the treatment effects were calculated as the weighted mean difference (WMD) and standard deviation (SD) in the change from baseline to follow-up in the green tea group versus control group. For crossover trials, the treatment effects were calculated as the WMD and SD at follow-up in the green tea intervention versus control periods. If the SD were not reported directly, the variances were imputed from 95\% CIs, $P$ values, standard error (SE), or $t$ values [17]. In addition, missing SD values for paired differences were imputed by assuming a correlation coefficient of 0.5 between variances at baselines and completion of trials according to the method of Follmann et al. [18]. The statistical heterogeneity of treatment effects between studies was evaluated via the Cochran's $Q$ test $(P<0.1$ was considered significant) and the inconsistency index $\left(I^{2}\right) . I^{2}>50 \%$ indicated significant heterogeneity across studies [19]. Random-effects models (DerSimonian and Laird), which considered both within- and betweenstudy variation, were performed for the studies used different doses, different populations, different durations and so on [20]. Primary outcome measures included WMD in FBG, FBI, and $\mathrm{HbA}_{1 \mathrm{c}}$ after green tea supplementation. The secondary outcome measures included WMD in HOMA-IR concentration.

Sensitivity analyses were used to evaluate the stability of the results by removing a single study each time to identify the effect of individual studies on the pooled effect size. Prespecified subgroup analyses were performed by catechins dosage $(\geq 500 \mathrm{mg} / \mathrm{d}$ compared with $<500 \mathrm{mg} / \mathrm{d}$ ), intervention type (green tea beverage compared with green tea capsule), participants' country (Asian compared with Western countries), study design (parallel compared with crossover), baseline fasting glucose level (high or normal), trial quality (low risk of bias, some concern or high risk of bias) and treatment duration ( $\geq 12$ weeks compared with $<12$ weeks). In addition, the study duration $<12$ weeks were defined as short duration for the changes of $\mathrm{HbA}_{1 \mathrm{c}}$ need to be monitored for at least 2-3 months. Meta-regression analysis was performed to examine the association between the net change in fasting glucose, fasting insulin or $\mathrm{HbA}_{1 \mathrm{c}}$ and intervention dose, treatment duration, intervention type, caffeine content, different ethnicity or study design. Publication bias was assessed by funnel plots and Egger's test [21]. A $P$ value of < 0.05 was considered statistically significant, unless otherwise specified.

\section{Results}

\section{Results of the literature search}

The search strategy identified 2324 abstracts. After the titles and abstracts were screened, 2229 articles were excluded and 95 articles underwent full-text review. A further 68 articles were excluded for the following reasons: 26 articles did not provide relevant outcomes, 14 articles involved green tea as a multicomponent supplement in the experimental group, 12 articles were excluded because the subjects had been treated with black tea or oolong tea.

5 studies were less than 2 weeks in duration and 11 articles did not report sufficient details for inclusion. Finally, 27 eligible articles met the inclusion criteria and were included in the meta-analysis (Fig. 1).

\section{Study characteristics}

Twenty seven eligible RCTs [22-48] were enrolled in this meta-analysis (Table 1). Twenty seven studies [2248] with 2194 subjects reported on FBG, 18 studies [23$27,29,31-37,39,43,44,48]$ with 1559 subjects reported data on FBI and 11 studies [22, 24, 27, 31, 32, 34, 37, 40, $41,43,48]$ with 767 subjects reported data on $\mathrm{HbA}_{1 \mathrm{c}}$. The green tea catechins intake ranged from 80 to 1344 $\mathrm{mg} / \mathrm{d}$, the trial size varied from 25 to 240 subjects and the study duration ranged from 3 weeks to12 months. (Table 1).

Of the 27 trials with 28 comparisons included in the current meta-analysis, 13 comparisons [22-25, 28-30, $33,36,39,46,48]$ were conducted in western countries and 15 comparisons [26, 27, 31, 32, 34, 35, 37, 38, 40$45,47]$ were conducted in Asian countries. Twenty comparisons [22-30, 33, 36, 38, 39, 41, 42, 45-48] were performed in subjects with normal FBG and 8 comparisons $[31,32,34,35,37,40,43,44]$ were performed in subjects with high level FBG. Most comparisons ( 25 of 28 ) used a parallel study design [22-24, 26-31, 33-43, 45-48], while others (3 comparisons) used a crossover design [25, 32, 44]. Twelve comparisons [22, 24, 25, 27, 29, 33, $35,37-39,48]$ adjusted for the confounding effect of caffeine on glucose and insulin, 13 comparisons [26, 28, $30-32,34,36,40-45]$ used caffeinated green tea, and 3 [23, 46, 47] did not report the use of coffee. Twenty comparisons [23-30, 33-40, 46-48] used green tea extract capsule and eight comparisons [22, 31, 32, 41-45] used green tea beverage (Table 1). 


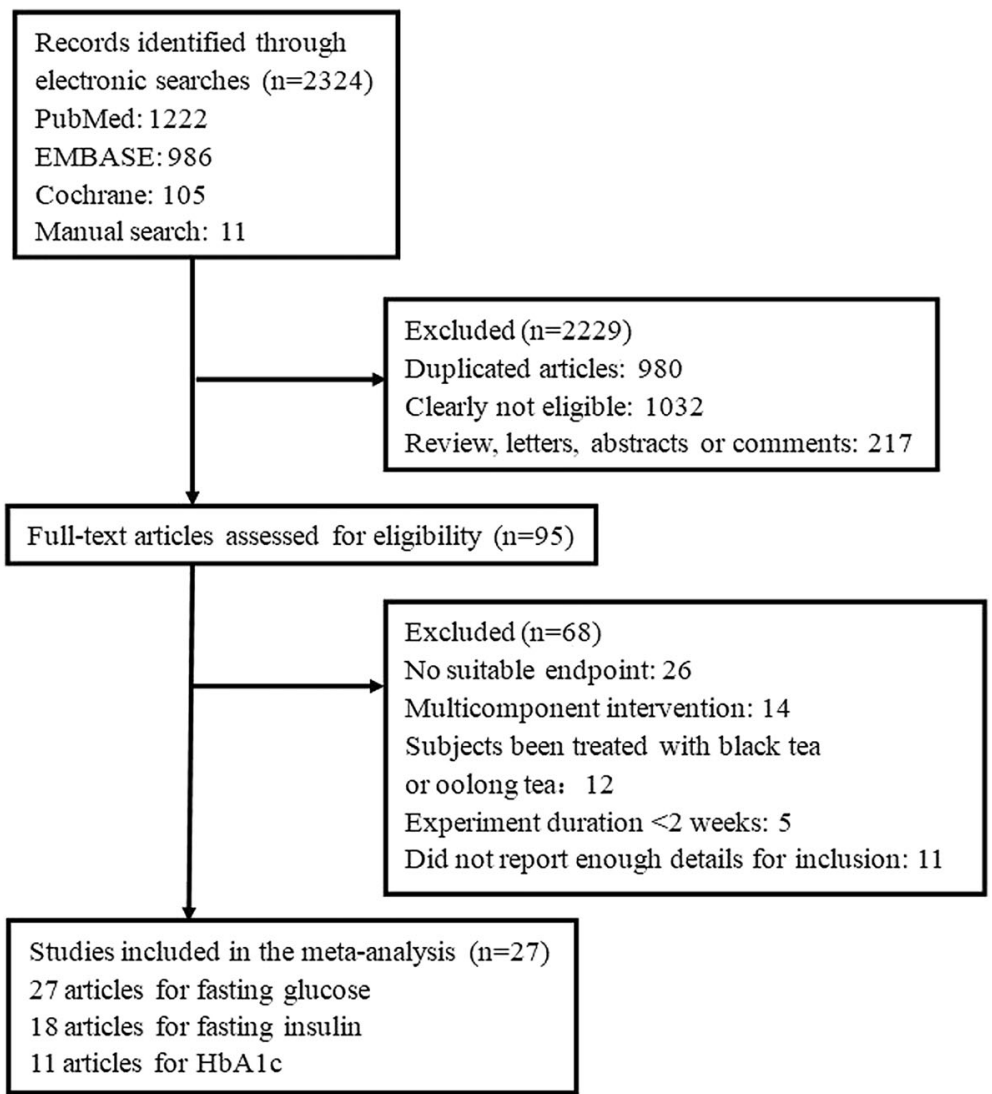

Fig. 1 Flow diagram of the trial selection process

\section{Data quality}

The study quality of the 27 included RCTs varied. Fourteen studies [22-27, 29, 34, 35, 38, 39, 45-47] were classified as high-quality (Jadad score $\geq 4$ ), and the remaining 13 studies [28, 30-33, 36, 37, 40-44, 48] were classified as low-quality (Jadad score $<4$ ). Most trials did not report details regarding allocation concealment (14 of 27) $[26,28,30-32,36,37,40-44,46,48]$ or randomization method (15 of 27) [23, 28, 30-33, 36, 37, 40-45, 48]. Twenty-two trials used double-blinded design [23-30, 34-43, 45-48], one trial used a singleblinded design [22], and four trials used an open-label design $[31-33,44]$. Three trials did not report the dropout rate or the reasons for the dropouts [28, 40, 44] (Table 2).

\section{Main outcomes}

Primary outcome measures included changes in FBG, $\mathrm{FBI}$, and $\mathrm{HbA}_{1 \mathrm{c}}$. Overall, green tea supplementation significantly decreased FBG concentration by $-1.44 \mathrm{mg} / \mathrm{dL}$ (95\%CI:-2.26, $\quad-0.62 \mathrm{mg} / \mathrm{dL} ; \quad P<0.001)$. Heterogeneity was not significant for this outcome $\left(I^{2}=7.7 \%, P=0.35\right)$ (Fig. 2). Green tea supplementation had no significant effect on FBI concentrations in the overall analysis
(WMD: $-0.46 \mu \mathrm{IU} / \mathrm{mL} ; 95 \% \mathrm{CI}:-1.10,0.17 \mu \mathrm{IU} / \mathrm{mL} ; P=$ $0.21)$. The overall test for heterogeneity was significant $\left(I^{2}=46.8 \% ; P=0.01\right)$ (Fig. 3$)$. In addition, there was no significant difference in serum $\mathrm{HbA}_{1 \mathrm{c}}$ concentration between green tea supplementation and placebo group (WMD: $-0.06 \%$; 95\% CI: $-0.12,0.01 \% ; P=0.07$ ), with mild heterogeneity $\left(I^{2}=1.7 \% ; P=0.43\right)$ (Fig. 4$)$.

Secondary outcome measures included changes in HOMA-IR concentration. Green tea supplementation had no significant effect on HOMA-IR (WMD: -0.15; 95\%CI:$0.39,0.10 ; P=0.24)$ compared with controls. Heterogeneity was not significant for this outcome $\left(I^{2}=34 \%, P=0.12\right)$.

\section{Subgroup analysis and meta-regression}

In the subgroup analysis, green tea consumption significantly lowered FBG concentrations in subjects using green tea capsule or with high catechins dosage, subjects from western countries, subjects in short duration of green tea supplementation, subjects with normal FBG, studies with caffeinated green tea intake, studies with parallel design, and studies with low quality. However, significant reduction in fasting glucose was not found in other subgroups. In addition, the beneficial effect for green tea supplementation on fasting insulin was 


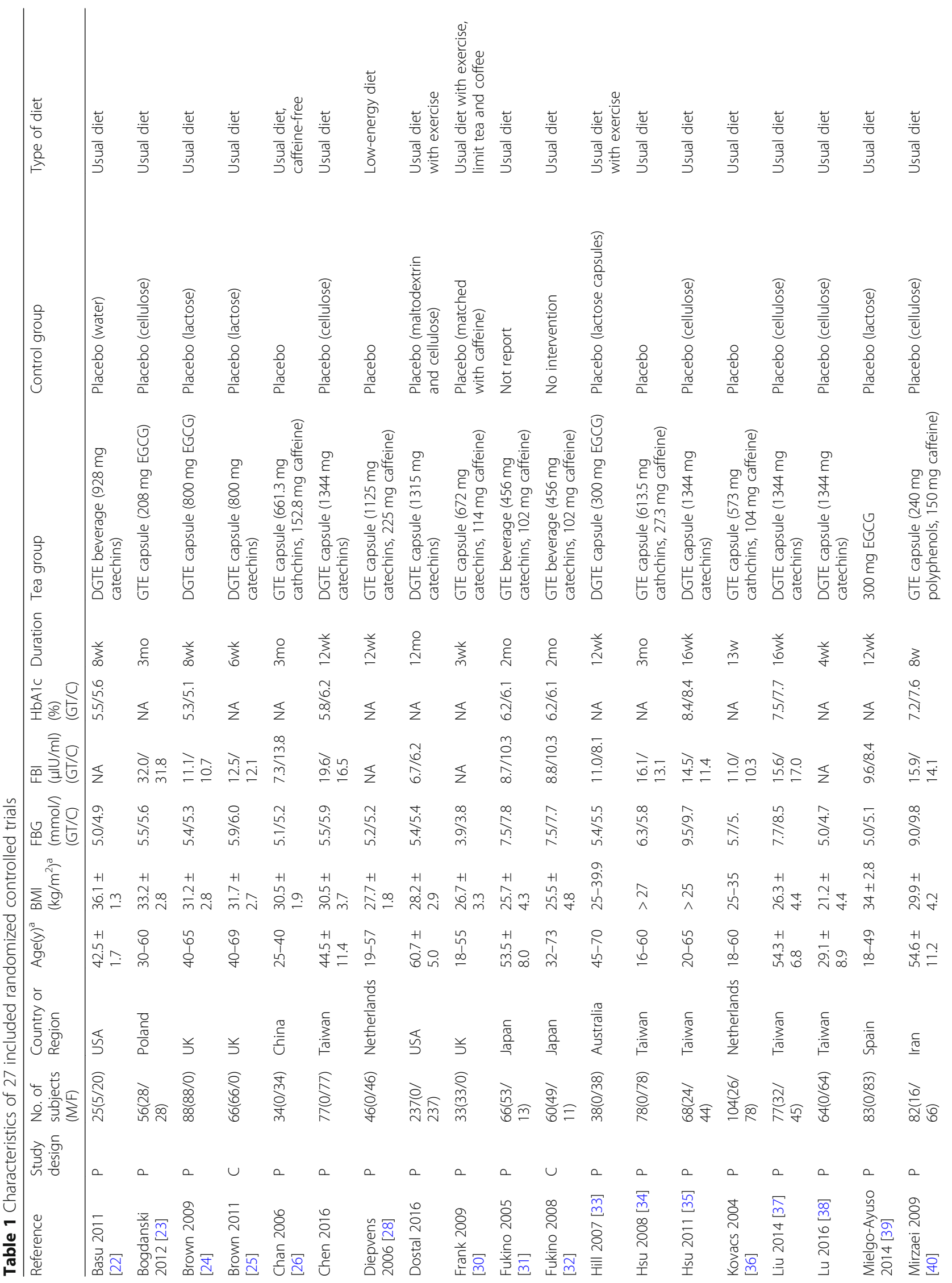




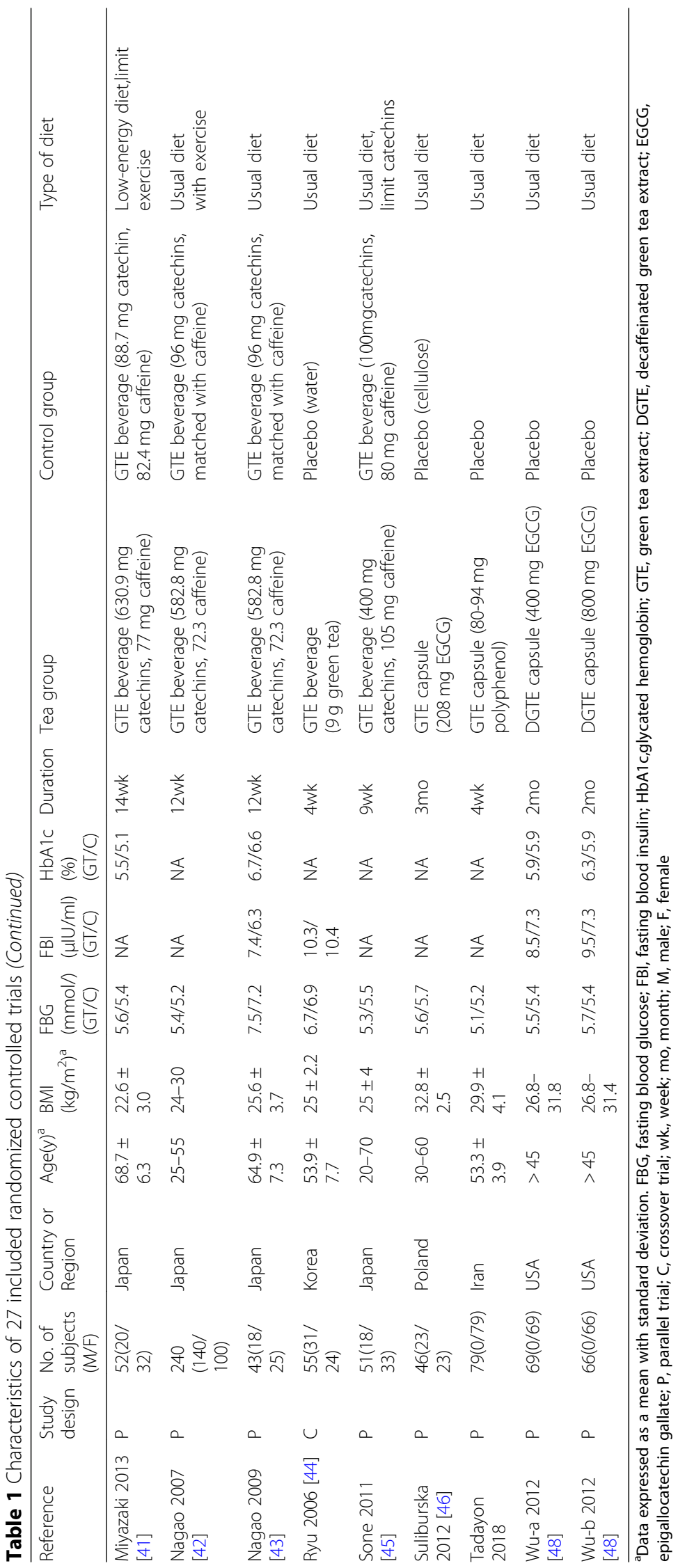


Table 2 Validity of included studies

\begin{tabular}{|c|c|c|c|c|c|c|c|}
\hline References & Randomization & $\begin{array}{l}\text { Allocation } \\
\text { concealment }\end{array}$ & $\begin{array}{l}\text { Masking of } \\
\text { participants }\end{array}$ & $\begin{array}{l}\text { Masking of } \\
\text { researches }\end{array}$ & $\begin{array}{l}\text { Generation of random } \\
\text { numbers reported }\end{array}$ & $\begin{array}{l}\text { Reporting of } \\
\text { withdraws }\end{array}$ & $\begin{array}{l}\text { Jadad } \\
\text { score }\end{array}$ \\
\hline Basu 2011 [22] & Yes & Adequate & Yes & No & Yes & Yes & 4 \\
\hline Bogdanski 2012 [23] & Yes & Adequate & Yes & Yes & No & Yes & 4 \\
\hline Brown 2009 [24] & Yes & Adequate & Yes & Yes & Yes & Yes & 5 \\
\hline Brown 2011 [25] & Yes & Adequate & Yes & Yes & Yes & Yes & 5 \\
\hline Chan 2006 [26] & Yes & Unclear & Yes & Yes & Yes & Yes & 4 \\
\hline Chen 2016 & Yes & Adequate & Yes & Yes & Yes & Yes & 5 \\
\hline Diepvens 2006 [28] & Yes & Unclear & Yes & Yes & No & No & 2 \\
\hline Dostal 2016 & Yes & Adequate & Yes & Yes & Yes & Yes & 5 \\
\hline Frank 2009 [30] & Yes & Unclear & Yes & Yes & No & Yes & 3 \\
\hline Fukino 2005 [31] & Yes & Unclear & No & No & No & Yes & 2 \\
\hline Fukino 2008 [32] & Yes & Unclear & No & No & No & Yes & 2 \\
\hline Hill 2007 [33] & Yes & Adequate & No & No & No & Yes & 3 \\
\hline Hsu 2008 [34] & Yes & Adequate & Yes & Yes & Yes & Yes & 5 \\
\hline Hsu 2011 [35] & Yes & Adequate & Yes & Yes & Yes & Yes & 5 \\
\hline Kovacs 2004 [36] & Yes & Unclear & Yes & Yes & No & Yes & 3 \\
\hline Liu 2014 [37] & Yes & Unclear & Yes & Yes & No & Yes & 3 \\
\hline Lu 2016 [38] & Yes & Adequate & Yes & Yes & Yes & Yes & 5 \\
\hline Mielgo-Ayuso 2014 [39] & Yes & Adequate & Yes & Yes & Yes & Yes & 5 \\
\hline Mirzaei 2009 [40] & Yes & Unclear & Yes & Yes & No & No & 2 \\
\hline Miyazaki 2013 [41] & Yes & Unclear & Yes & Yes & No & Yes & 3 \\
\hline Nagao 2007 [42] & Yes & Unclear & Yes & Yes & No & Yes & 3 \\
\hline Nagao 2009 [43] & Yes & Unclear & Yes & Yes & No & Yes & 3 \\
\hline Ryu 2006 [44] & Yes & Unclear & No & No & No & No & 1 \\
\hline Sone 2011 [45] & Yes & Adequate & Yes & Yes & No & Yes & 4 \\
\hline Suliburska 2012 [46] & Yes & Unclear & Yes & Yes & Yes & Yes & 4 \\
\hline Tadayon 2018 & Yes & Adequate & Yes & Yes & Yes & Yes & 5 \\
\hline Wu 2012 [48] & Yes & Unclear & Yes & Yes & No & Yes & 3 \\
\hline
\end{tabular}

observed in subjects with green tea capsule, subjects from western countries, subjects with normal baseline FBG and studies with decaffeinated green tea intake. However, no effect was found in other subgroups. Significant reductions in $\mathrm{HbA}_{1 \mathrm{c}}$ concentrations were observed in subjects from Asian countries, studies with caffeine in green tea and studies with low quality, while the obvious effect was not found in other subgroups (Table 3).

Meta-regression found no linear relations between WMD in FBG, FBI or $\mathrm{HbA}_{1 \mathrm{C}}$ and intervention dose (Fig. 5). Furthermore, meta-regression found no linear relations between WMD in FBG or FBI and treatment duration, caffeine content, different ethnicity, intervention type and study design. In contrast, meta-regression by intervention type (beverage or capsule) did impact the WMD in $\mathrm{HbA}_{1 \mathrm{C}}$ for green tea consumption versus control group $(P=0.021)$, while, there was no linear relations between WMD in $\mathrm{HbA}_{1 \mathrm{C}}$ and other subgroups.

\section{Publication bias}

The funnel plots of the studies were symmetrical for fasting glucose, fasting insulin, and $\mathrm{HbA}_{1 \mathrm{c}}$ (Supplementary Figure 1). Furthermore, the results of the Egger's test did not support the existence of publication bias for fasting glucose $(P=0.18)$, fasting insulin $(P=0.58)$, and $\mathrm{HbA}_{1 \mathrm{c}}(P=0.45)$.

A sensitivity analysis was performed to confirm the robustness of our findings. In a sensitivity analysis, in which one study was removed at a time and the remaining studies analyzed, the pooled reductions in fasting glucose ranged from $-1.55 \mathrm{mg} / \mathrm{dL}(95 \% \mathrm{CI}:-2.39,-0.70 \mathrm{mg} / \mathrm{dL})$ to $-1.16 \mathrm{mg} / \mathrm{dL}(95 \% \mathrm{CI}:-2.10,-0.22 \mathrm{mg} / \mathrm{dL}$ ); and the pooled reductions in fasting insulin ranged from -0.59 


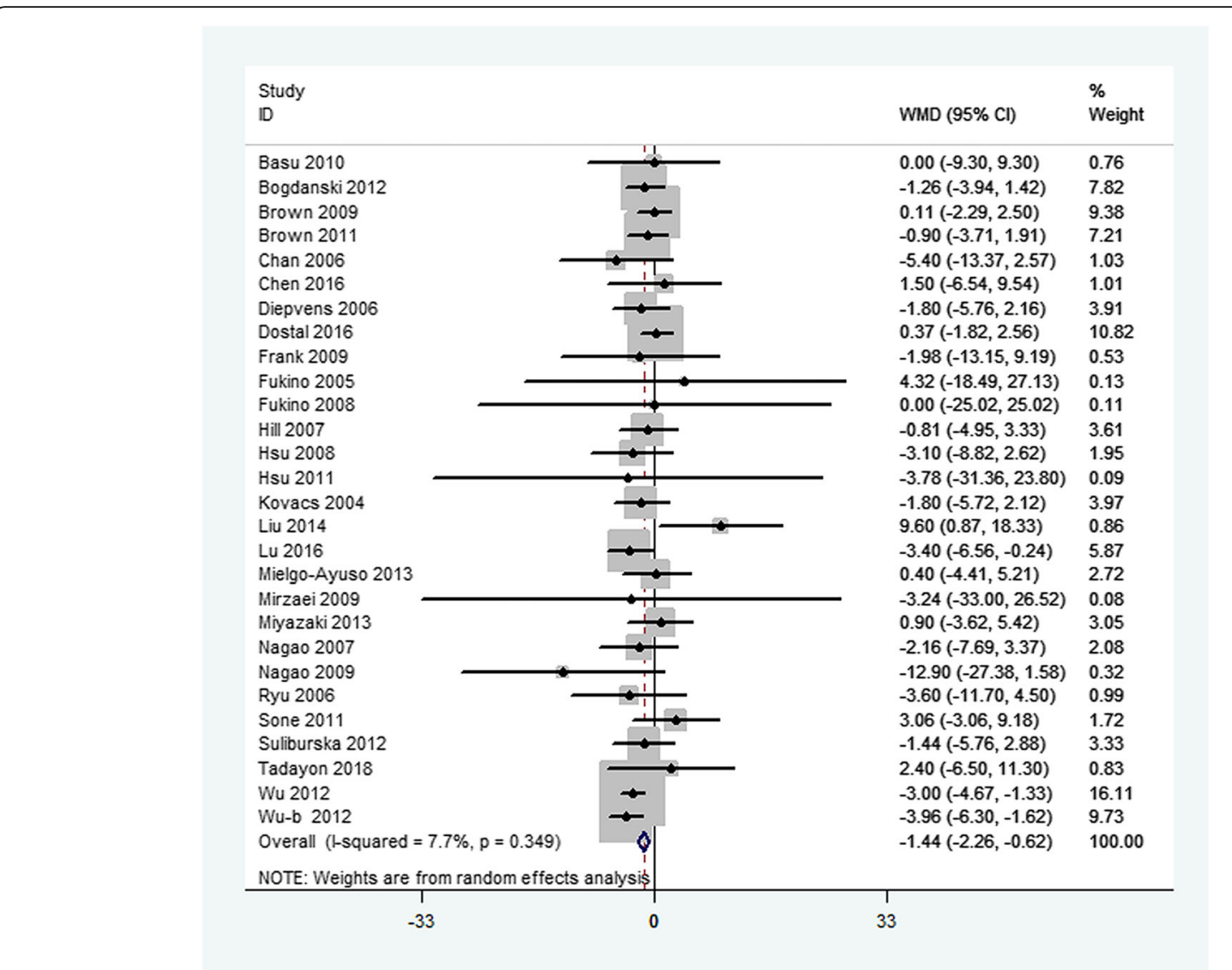

Fig. 2 Meta-analysis of the effects of green tea on fasting blood glucose concentrations. Results from individual trials were pooled with the use of random-effect models and are expressed as weighted mean differences with 95\% Cls

(95\% CI: $-1.21,0.02)$ to -0.23 (95\% CI: $-0.87,0.42)$. The result was consistent after removing each trial for both fasting glucose and fasting insulin. In the sensitivity analysis of $\mathrm{HbA}_{1 \mathrm{c}}$, the exclusion of one trial [22] (Basu 2011) resulted in significant reductions of- 0.08 (95\% CI: -0.14 , - 0.01) in $\mathrm{HbA}_{1 \mathrm{c}}$. However, there was no significant reduction in $\mathrm{HbA}_{1 \mathrm{c}}$ after the removal of other trials.

\section{Discussion}

This meta-analysis involving 27 RCTs with 2194 subjects evaluated the effect of green tea supplementation on glycemic control. We found that green tea supplementation significantly reduced FBG concentration, while the effect of green tea on other glycemic variables such as FBI, $\mathrm{HbA}_{1 \mathrm{c}}$, and HOMA-IR was not significant.

Our results are consistent with some previous metaanalysis $[49,50]$, which also showed that green tea consumption resulted in a significant reduction in FBG. While, another previous meta-analysis [8] suggested that green tea consumption had favorable effects on decreasing both $\mathrm{FBG}$ and $\mathrm{HbA}_{1 \mathrm{c}}$ concentrations. In our study, we did not find a significant improvement in $\mathrm{HbA}_{1 \mathrm{c}}$ concentrations. In more than half of the included trials, the intervention duration was less than 12 weeks. However, $\mathrm{HbA}_{1 \mathrm{c}}$ changes need to be monitored for at least 2-3 months when evaluating the progression of diabetes. Observational prospective cohorts and case-control studies have been performed to determine the effect of green tea supplementation on glycemic control, although the results are conflicting. In particular, A large epidemiological study conducted in Japan have indicated that daily tea consumption ( $>6$ cups/day) was associated with a decreased risk for diabetes [51] . Some RCTs also found beneficial effects on glycemic control, including reducing fasting glucose and fasting insulin [38, 48]. In contrast, several RCTs have reported no significant correlations between green tea intake and glycemic control $[24,27]$. Nonetheless, these results need to be interpreted with caution because the number of patients enrolled in most trials was too limited, at less than 100 patients; in addition, the intervention duration and catechins dosages were varied among studies. So, more 


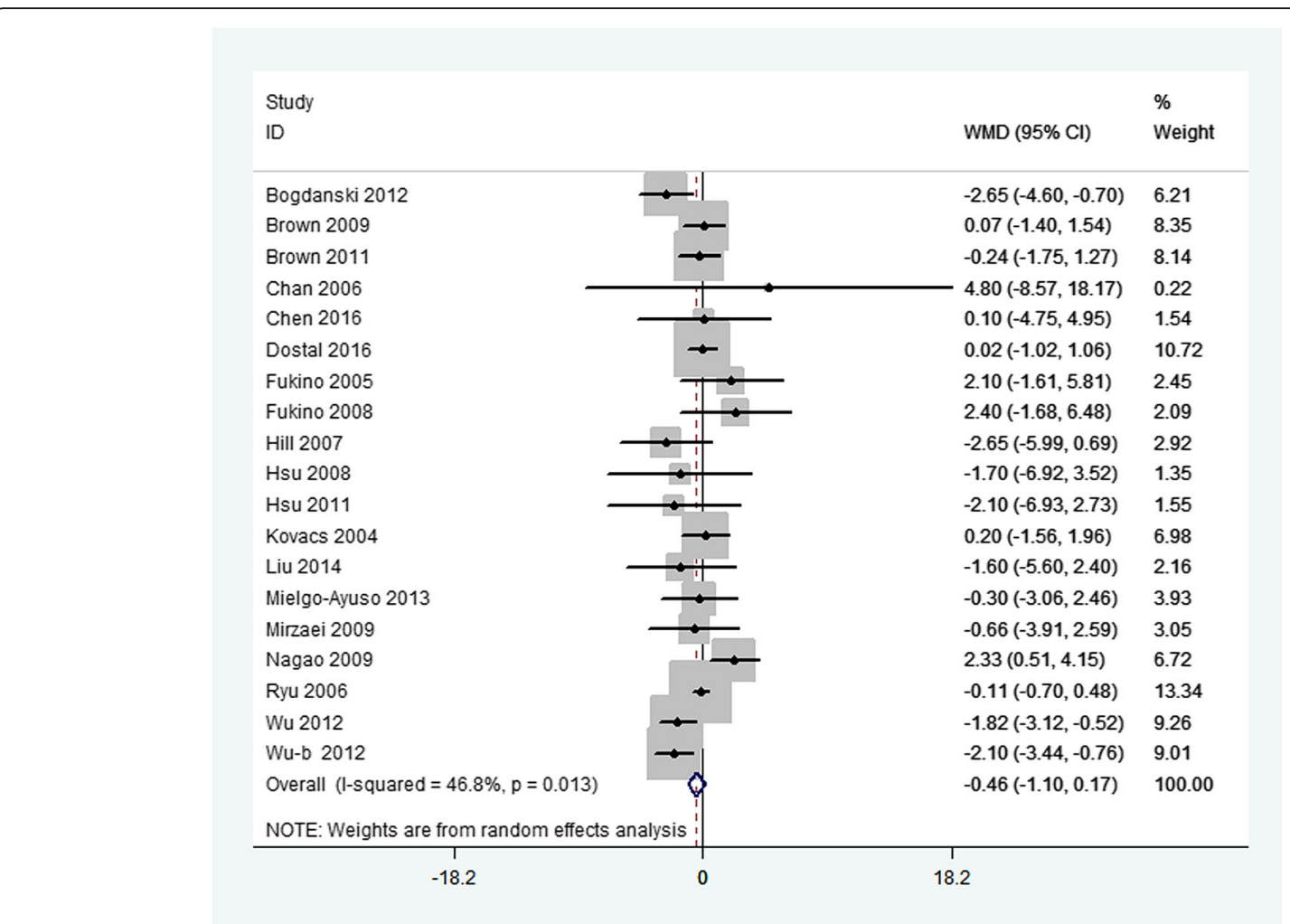

Fig. 3 Meta-analysis of the effects of green tea on fasting blood insulin concentrations. Results from individual trials were pooled with the use of random-effect models and are expressed as weighted mean differences with $95 \% \mathrm{Cls}$

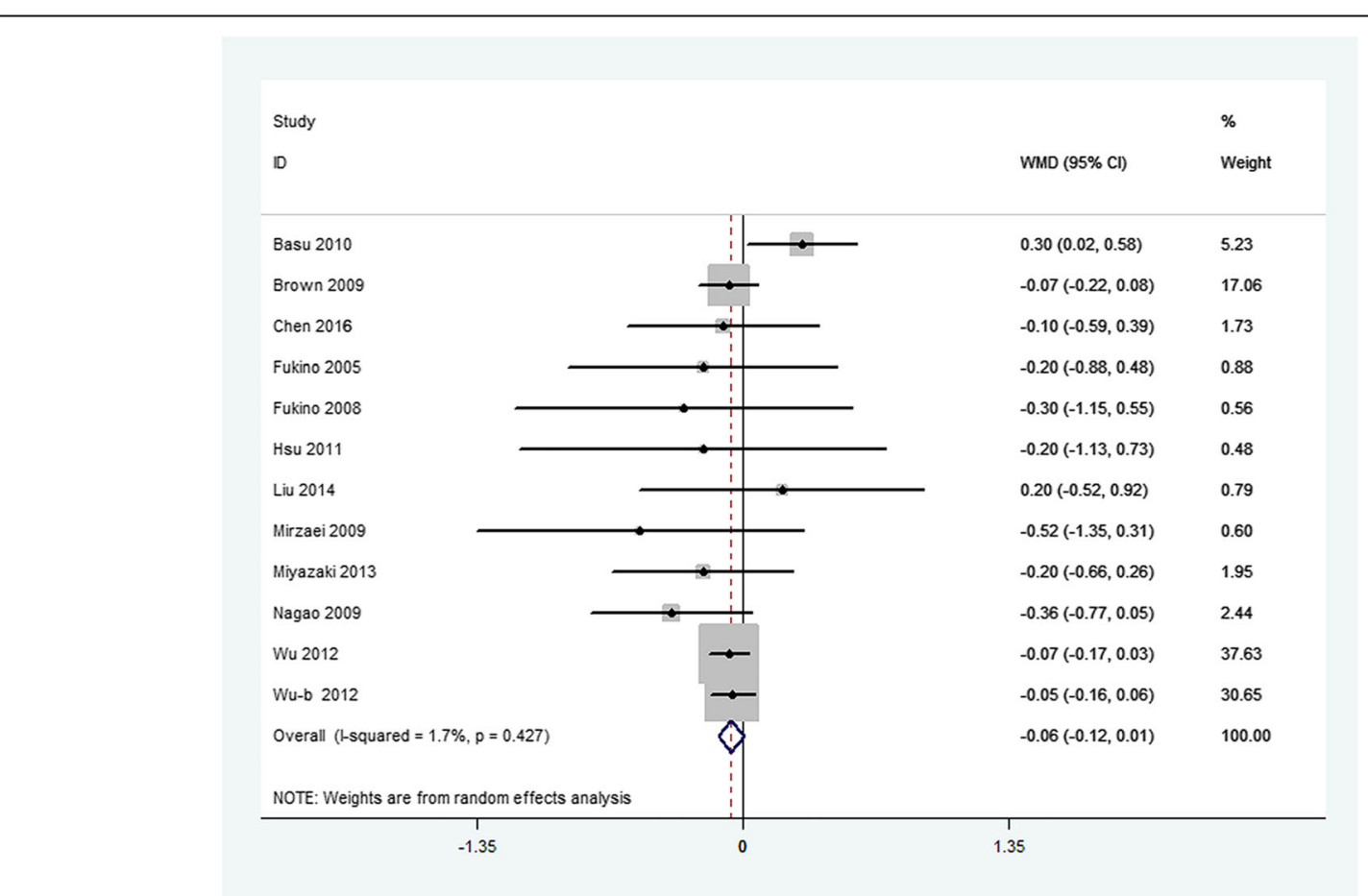

Fig. 4 Meta-analysis of the effects of green tea on $\mathrm{HbA}_{k}$ concentrations. Results from individual trials were pooled with the use of random-effect models and are expressed as weighted mean differences with 95\% Cls 
Table 3 Subgroup analyses of fasting blood glucose, fasting blood insulin and HbA1c stratified by previously defined study characteristics

\begin{tabular}{|c|c|c|c|c|c|c|c|c|c|}
\hline \multirow[b]{2}{*}{ Subgroup } & \multicolumn{3}{|c|}{ Change in FBG } & \multicolumn{3}{|c|}{ Change in FBI } & \multicolumn{3}{|c|}{ Change in $\mathrm{HbA} 1 \mathrm{c}$} \\
\hline & $\begin{array}{l}\text { Trials } \\
\text { (n) }\end{array}$ & $\begin{array}{l}\text { Net change } \\
(95 \% \mathrm{Cl})(\mathrm{mg} / \mathrm{dl})\end{array}$ & $\overline{1^{2}}$ & $\begin{array}{l}\text { Trials } \\
\text { (n) }\end{array}$ & $\begin{array}{l}\text { Net change }(95 \% \mathrm{Cl})(\mathrm{mg} / \\
\text { dl) }\end{array}$ & $1^{2}$ & $\begin{array}{l}\text { Trials } \\
\text { (n) }\end{array}$ & $\begin{array}{l}\text { Net change }(95 \% \mathrm{Cl})(\mathrm{mg} / \\
\mathrm{dl})\end{array}$ & $1^{2}$ \\
\hline \multicolumn{10}{|l|}{ Type of intervention } \\
\hline Green tea beverage & 8 & $-0.37(-3.00,2.27)$ & 0 & 4 & $1.28(-0.48,3.03)$ & 64 & 5 & $-0.10(-0.42,0.22)$ & 55 \\
\hline Green tea capsule & 20 & $-1.63(-2.60,-0.66)$ & 22 & 15 & $-0.88(-1.54,-0.22)$ & 29 & 7 & $-0.06(-0.13,0.00)$ & 0 \\
\hline \multicolumn{10}{|l|}{ Duration } \\
\hline$\geq 12$ weeks & 15 & $-1.04(-2.30,0.22)$ & 12 & 11 & $-0.35(-1.48,0.78)$ & 47 & 5 & $-0.19(-0.42,0.05)$ & 0 \\
\hline$<12$ weeks & 13 & $\begin{array}{l}-2.09(-3.14,- \\
1.03)\end{array}$ & 4 & 8 & $-0.55(-1.41,0.30)$ & 56 & 7 & $-0.04(-0.13,0.05)$ & 25 \\
\hline \multicolumn{10}{|l|}{ Country } \\
\hline Western & 13 & $\begin{array}{l}-1.60(-2.50,- \\
0.69)\end{array}$ & 11 & 9 & $-0.88(-1.71,-0.05)$ & 56 & 4 & $-0.02(-0.13,0.08)$ & 52 \\
\hline Asian & 15 & $-1.20(-3.30,0.90)$ & 20 & 10 & $0.40(-0.58,1.37)$ & 20 & 8 & $-0.22(-0.42,-0.01)$ & 0 \\
\hline \multicolumn{10}{|l|}{ Catechins dose } \\
\hline$\geq 500 \mathrm{mg} / \mathrm{dl}$ & 17 & $-1.68(-2.93,-0.43)$ & 39 & 11 & $-0.32(-1.24,0.60)$ & 58 & 9 & $-0.05(-0.13,0.03)$ & 16 \\
\hline$<500 \mathrm{mg} / \mathrm{dl}$ & 10 & $-0.82(-2.46,0.83)$ & 0 & 7 & $-0.79(-2.31,0.74)$ & 36 & 3 & $-0.32(-0.77,0.13)$ & 0 \\
\hline \multicolumn{10}{|l|}{ Caffeine } \\
\hline With caffeine & 13 & $-2.00(-3.78,-0.22)$ & 0 & 8 & $0.72(-0.29,1.73)$ & 31 & 5 & $-0.30(-0.55,-0.05)$ & 0 \\
\hline Without caffeine & 12 & $-1.25(-2.65,0.15)$ & 47 & 10 & $-0.89(-1.59,-0.19)$ & 27 & 7 & $-0.04(-0.11,0.04)$ & 12 \\
\hline \multicolumn{10}{|l|}{ Study design } \\
\hline Parallel & 25 & $-1.51(-2.49,-0.53)$ & 21 & 16 & $-0.57(-1.43,0.28)$ & 53 & 11 & $-0.06(-0.13,0.02)$ & 8 \\
\hline Crossover & 3 & $-1.17(-3.80,1.46)$ & 0 & 3 & $-0.08(-0.63,0.46)$ & 0 & 1 & $-0.30(-1.15,0.55)$ & NA \\
\hline \multicolumn{10}{|l|}{ Fasting blood glucose } \\
\hline High(> $6.1 \mathrm{mmol} / \mathrm{l})$ & 8 & $-1.16(-6.22,3.90)$ & 26 & 8 & $0.41(-0.75,1.57)$ & 35 & 6 & $-0.26(-0.52,0.01)$ & 0 \\
\hline $\begin{array}{l}\text { Normal }(3.9-6.1 \mathrm{mmol} / \\
\text { I) }\end{array}$ & 20 & $-1.56(-2.41,-0.72)$ & 11 & 11 & $-0.83(-1.61,-0.05)$ & 47 & 6 & $-0.04(-0.12,0.04)$ & 26 \\
\hline \multicolumn{10}{|l|}{ Study quality } \\
\hline High quality & 14 & $-0.77(-1.78,0.24)$ & 0 & 9 & $-0.39(-1.04,0.27)$ & 0 & 4 & $0.03(-0.20,0.27)$ & 47 \\
\hline Low quality & 14 & $-2.44(-3.74,-1.15)$ & 10 & 10 & $-0.27(-1.33,0.79)$ & 67 & 8 & $-0.08(-0.15,-0.01)$ & 0 \\
\hline
\end{tabular}

$F B G$ fasting blood glucose, $F B I$ fasting blood insulin, $H b A_{1 c}$ glycated hemoglobin, $N A$ not applicable

RCTs with larger subjects and longer duration were needed to find out the real relationship between green tea consumption and blood glucose control.

Recent mechanistic studies have examined the effects of green tea consumption on glucose control and provided further evidence for the biological plausibility of these findings. Green tea may affect glucose control through different mechanisms. First, tea catechins have been reported to reduce carbohydrate absorption from the intestine via inhibition of intestinal sucrose, alphaamylase, and alpha-glucosidase [10]. Second, Tea catechins might also inhibit the hepatic gluconeogenesis through regulation of the expression of gluconeogenic genes and protein-tyrosine phosphorylation in the mouse liver [52]. Third, tea catechins could enhance insulin sensitivity and glucose metabolism there by helping to prevent the development of T2DM [53]. Furthermore,
Tea catechins are also powerful antioxidants that can ameliorate oxidative stress [54].

In this meta-analysis, subgroup analyses were performed based on predefined variables to identify potential sources of heterogeneity. Green tea consumption significantly decreased FBG and FBI only in subjects using green tea capsule. In addition, meta-regression also pointed out that green tea capsule was associated with $\mathrm{HbA}_{1 \mathrm{C}}$. Nowadays, there was still insufficient evidence on whether green tea capsule was more biologically active compared to green tea beverage in vivo or vitro studies. In addition, subgroup analyses revealed that green tea with caffeine had a more pronounced effect on FBG and $\mathrm{HbA}_{1 \mathrm{C}}$ than the decaffeination subgroup. As tea naturally contains caffeine in addition to catechins and other compounds, whether caffeine intake influences the glucose control of tea remains controversial $[55,56]$. As there were a limited number of 
A

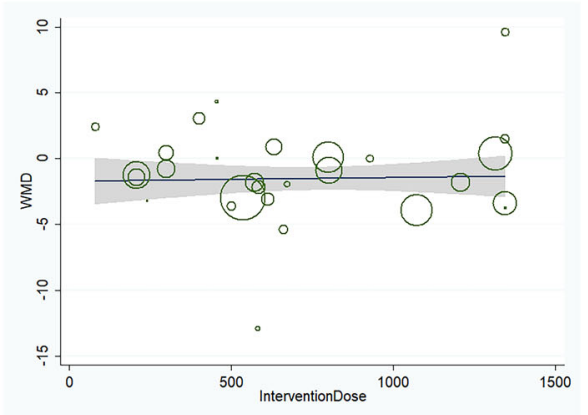

C

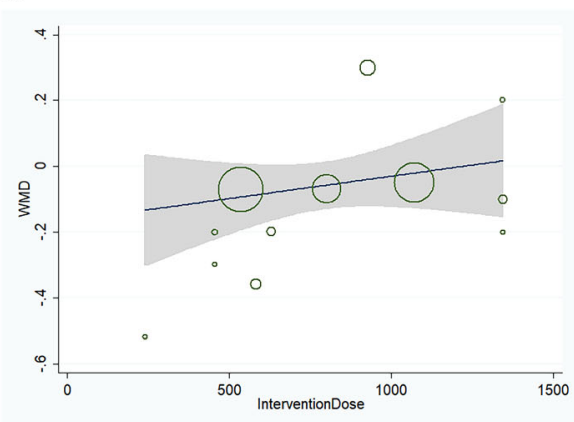

B

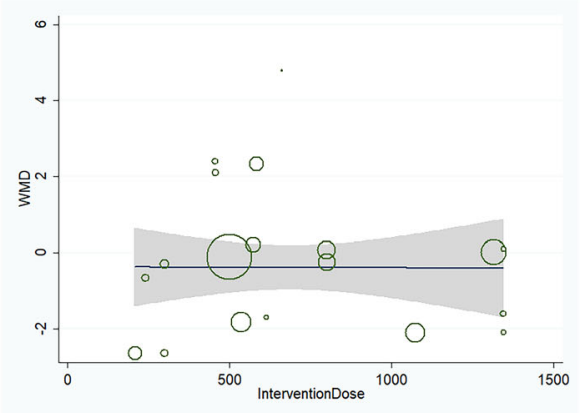

Fig. 5 a Relation between the WMD of FBG and intervention dose in 27 independent randomized controlled comparisons. $\mathbf{b}$ Relation between the WMD of FBI and intervention dose in 18 independent randomized controlled comparisons. c Relation between the WMD of HbA $\mathrm{A}_{\mathrm{Ic}}$ and intervention dose in 11 independent randomized controlled comparisons. Each circle represents a study, telescoped by its weight in the analysis. Meta-regression found no linear relations between WMD in FBG $(P=0.89), \mathrm{FBI}(P=0.97)$, or $\mathrm{HbA}_{\mathrm{Ic}}(P=0.25)$ and intervention dose

subjects in the subgroup analysis, these results may not be generalized.

Our study had several strengths. First, we only selected RCTs in this meta-analysis, which ensured a relatively high-quality and provided reliable inference about causality. Second, both parallel and crossover studies were included in this meta-analysis. Crossover trials are generally considered to have a more-robust design than parallel trials because of reduced intraparticipant variability. We considered it important to include all these studies because they represented a comprehensive evidence for our analysis. Third, results were less likely to be influenced by publication bias. Furthermore, subgroup analyses were undertaken to detect potential sources of heterogeneity for primary outcomes.

Our study also had several limitations. First, the studies had relatively short durations of follow-up ranging from 3 weeks to 12 months. The intervention durations were less than 12 weeks in almost half of the included studies. In particular, $\mathrm{HbA}_{1 \mathrm{c}}$ changes need to be monitored for at least 23 months when evaluating the progression of diabetes. $\mathrm{HbA}_{1 \mathrm{c}}$ is an important indicator for glucose control, including greater pre-analytical stability, greater convenience, and less day-to-day perturbations. In addition, it also takes a number of months to detect delayed effects of green tea on insulin resistance. Therefore, RCTs with at least 3 months intervention duration might be more appropriate to assess the effects of green tea on glycemic control. Second, although significant effect of green tea intake on fasting glucose was observed in our study, we did not provide an optimal dosage of green tea supplementation that would maximize the improvement of glycemic control as the catechin dosage varied from 80 to $1344 \mathrm{mg} / \mathrm{d}$ and no consensus has been achieved. In addition, we could not ascertain the safety margin in this meta-analysis because no serious side effects were reported in the included trials. However, mild side effects such as mild skin rashes, gastric disturbances, and abdominal bloating were reported in some clinical studies [57]. Third, the size of these trials, which ranged between 25 and 240 participants, were indeed limited. Therefore, our meta-analysis may have been underpowered to detect a true effect. Forth, the quality of RCTs included in this meta-analysis varied. Some of the RCTs did not provide detailed randomization process. Of the 27 trials, almost half of the trials were of high risk of bias, which may also affect the reliability of our findings.

\section{Conclusion}

In conclusion, green tea intake had a favorable effect on fasting blood glucose concentration. However, green tea intake did not significantly affect fasting blood insulin or 
$\mathrm{HbA}_{1 \mathrm{c}}$. In future, high-quality larger RCTs with longterm follow-up are needed to investigate the effect of green tea supplementation on glycemic control, especially the long-term effects on fasting insulin and $\mathrm{HbA}_{1 \mathrm{c}}$.

\section{Supplementary information}

Supplementary information accompanies this paper at https://doi.org/10. 1186/s12986-020-00469-5.

\section{Additional file 1: Figure 1. A. Funnel plot of green tea} supplementation and FBG. B. Funnel plot of green tea supplementation and FBI. C. Funnel plot of green tea supplementation and $\mathrm{HbA} \mathrm{A}_{\mathrm{c}}$.

\section{Abbreviations}

Cls: Confidence intervals; EGCG: Epigallocatechin gallate; FBG: Fasting blood glucose; FBI: Fasting blood insulin; HbA1c: Glycated hemoglobin; HOMAIR: Homeostatic model assessment of insulin resistance; PRISMA: Systematic Reviews and Meta-Analyses; RCTs: Randomized placebo-controlled trials; SD: Standard deviation; SE: Standard error; T2DM: Type 2 diabetes mellitus; WMD: Weighted mean difference

\section{Acknowledgments}

Not applicable

\section{Authors' contributions}

RFX searched databases, selected studies, extracted data, analyzed data and wrote the manuscript. YB searched databases and selected studies. KY extracted data, reviewed and edited the manuscript. GZC analyzed data, contributed to the design and discussion, reviewed and edited the manuscript. All authors read and approved the final manuscript.

\section{Funding}

The present study was supported by the National Natural Science Foundation of China (No. 81500293).

\section{Availability of data and materials}

All data generated or analyzed during this study are included in this published article.

\section{Ethics approval and consent to participate}

Not applicable.

\section{Consent for publication}

Not applicable.

\section{Competing interests}

The authors declare that they have no competing interests.

\section{Author details \\ 'Department of Medical Ultrasound, Tongji Hospital, Tongji Medical College, Huazhong University of Science and Technology, Wuhan 430030, P.R. China. 2Division of Cardiology, Department of Internal Medicine, Tongji Hospital, Tongji Medical College, Huazhong University of Science and Technology, Wuhan 430030, P.R. China.}

Received: 17 March 2020 Accepted: 24 June 2020

Published online: 10 July 2020

\section{References}

1. Pittas AG, Dawson-Hughes B, Sheehan P, Ware JH, Knowler WC, Aroda VR, Brodsky I, Ceglia L, Chadha C, Chatterjee R, Desouza C, Dolor R, Foreyt J, Fuss P, Ghazi A, Hsia DS, Johnson KC, Kashyap SR, Kim S, LeBlanc ES, Lewis MR, Liao E, Neff LM, Nelson J, O'Neil P, Park J, Peters A, Phillips LS, Pratley R, Raskin P, Rasouli N, Robbins D, Rosen C, Vickery EM, Staten M, Group DdR. Vitamin D supplementation and prevention of type 2 diabetes. N Engl J Med. 2019;381:520-30.
2. Cho NH, Shaw JE, Karuranga S, Huang Y, da Rocha Fernandes JD, Ohlrogge AW, Malanda B. IDF diabetes atlas: global estimates of diabetes prevalence for 2017 and projections for 2045. Diabetes Res Clin Pract. 2018;138:271-81.

3. Knowler WC, Barrett-Connor E, Fowler SE, Hamman RF, Lachin JM, Walker EA, Nathan DM. Diabetes prevention program research G: reduction in the incidence of type 2 diabetes with lifestyle intervention or metformin. N Engl J Med. 2002;346:393-403.

4. Lotfy M, Adeghate J, Kalasz H, Singh J, Adeghate E. Chronic complications of diabetes mellitus: a mini review. Curr Diabetes Rev. 2017;13:3-10.

5. Hou LQ, Liu YH, Zhang YY. Garlic intake lowers fasting blood glucose: metaanalysis of randomized controlled trials. Asia Pac J Clin Nutr. 2015;24:575-82.

6. Balentine DA, Wiseman SA, Bouwens LC. The chemistry of tea flavonoids. Crit Rev Food Sci Nutr. 1997:37:693-704.

7. Khan N, Mukhtar H. Tea polyphenols for health promotion. Life Sci. 2007;81: 519-33.

8. Liu K, Zhou R, Wang B, Chen K, Shi LY, Zhu JD, Mi MT. Effect of green tea on glucose control and insulin sensitivity: a meta-analysis of 17 randomized controlled trials. Am J Clin Nutr. 2013;98:340-8.

9. Jing Y, Han G, Hu Y, Bi Y, Li L, Zhu D. Tea consumption and risk of type 2 diabetes: a meta-analysis of cohort studies. J Gen Intern Med. 2009;24:557-62.

10. Collins QF, Liu HY, Pi J, Liu Z, Quon MJ, Cao W. Epigallocatechin-3-gallate (EGCG), a green tea polyphenol, suppresses hepatic gluconeogenesis through 5'-AMP-activated protein kinase. J Biol Chem. 2007:282:30143-9.

11. Wu LY, Juan CC, Hwang LS, Hsu YP, Ho PH, Ho LT. Green tea supplementation ameliorates insulin resistance and increases glucose transporter IV content in a fructose-fed rat model. Eur J Nutr. 2004;43:116-24.

12. Belcaro G, Ledda A, Hu S, Cesarone MR, Feragalli B, Dugall M. Greenselect phytosome for borderline metabolic syndrome. Evid Based Complement Alternat Med. 2013;2013:869061.

13. Igarashi Y, Obara T, Ishikuro M, Matsubara H, Shigihara M, Metoki H, Kikuya M, Sameshima Y, Tachibana H, Maeda-Yamamoto M, Kuriyama S. Randomized controlled trial of the effects of consumption of 'Yabukita' or 'Benifuuki' encapsulated tea-powder on low-density lipoprotein cholesterol level and body weight. Food Nutr Res. 2017;61:1334484.

14. Josic J, Olsson AT, Wickeberg J, Lindstedt S, Hlebowicz J. Does green tea affect postprandial glucose, insulin and satiety in healthy subjects: a randomized controlled trial. Nutr J. 2010;9:63.

15. Stroup DF, Berlin JA, Morton SC, Olkin I, Williamson GD, Rennie D, Moher D, Becker BJ, Sipe TA, Thacker SB. Meta-analysis of observational studies in epidemiology: a proposal for reporting. Meta-analysis of observational studies in epidemiology (MOOSE) group. JAMA. 2000;283:2008-12.

16. Moher D, Pham B, Jones A, Cook DJ, Jadad AR, Moher M, Tugwell P, Klassen TP. Does quality of reports of randomised trials affect estimates of intervention efficacy reported in meta-analyses? Lancet. 1998;352:609-13.

17. Anzures-Cabrera J, Sarpatwari A, Higgins JP. Expressing findings from meta-analyses of continuous outcomes in terms of risks. Stat Med. 2011:30:2967-85

18. Follmann D, Elliott $P$, Suh I, Cutler J. Variance imputation for overviews of clinical trials with continuous response. J Clin Epidemiol. 1992;45:769-73.

19. Higgins JP, Thompson SG. Quantifying heterogeneity in a meta-analysis. Stat Med. 2002;21:1539-58.

20. DerSimonian R, Laird N. Meta-analysis in clinical trials. Control Clin Trials, 1986:7:177-88

21. Egger M, Davey Smith G, Schneider M, Minder C. Bias in meta-analysis detected by a simple, graphical test. BMJ. 1997:315:629-34.

22. Basu A, Du M, Sanchez K, Leyva MJ, Betts NM, Blevins S, Wu M, Aston CE, Lyons TJ. Green tea minimally affects biomarkers of inflammation in obese subjects with metabolic syndrome. Nutrition. 2011;27:206-13.

23. Bogdanski P, Suliburska J, Szulinska M, Stepien M, Pupek-Musialik D, Jablecka A. Green tea extract reduces blood pressure, inflammatory biomarkers, and oxidative stress and improves parameters associated with insulin resistance in obese, hypertensive patients. Nutr Res. 2012;32:421-7.

24. Brown AL, Lane J, Coverly J, Stocks J, Jackson S, Stephen A, Bluck L, Coward A, Hendrickx $\mathrm{H}$. Effects of dietary supplementation with the green tea polyphenol epigallocatechin-3-gallate on insulin resistance and associated metabolic risk factors: randomized controlled trial. Br J Nutr. 2009;101:886-94.

25. Brown AL, Lane J, Holyoak C, Nicol B, Mayes AE, Dadd T. Health effects of green tea catechins in overweight and obese men: a randomised controlled cross-over trial. Br J Nutr. 2011;106:1880-9.

26. Chan CC, Koo MW, Ng EH, Tang OS, Yeung WS, Ho PC. Effects of Chinese green tea on weight, and hormonal and biochemical profiles in obese 
patients with polycystic ovary syndrome--a randomized placebo-controlled trial. J Soc Gynecol Investig. 2006;13:63-8.

27. Chen IJ, Liu CY, Chiu JP, Hsu CH. Therapeutic effect of high-dose green tea extract on weight reduction: a randomized, double-blind, placebocontrolled clinical trial. Clin Nutr. 2016;35:592-9.

28. Diepvens K, Kovacs EM, Vogels N, Westerterp-Plantenga MS. Metabolic effects of green tea and of phases of weight loss. Physiol Behav. 2006;87: 185-91.

29. Dostal AM, Samavat H, Espejo L, Arikawa AY, Stendell-Hollis NR, Kurzer MS. Green tea extract and catechol-O-methyltransferase genotype modify fasting serum insulin and plasma Adiponectin concentrations in a randomized controlled trial of overweight and obese postmenopausal women. J Nutr. 2016;146:38-45.

30. Frank J, George TW, Lodge JK, Rodriguez-Mateos AM, Spencer JP, Minihane AM, Rimbach G. Daily consumption of an aqueous green tea extract supplement does not impair liver function or alter cardiovascular disease risk biomarkers in healthy men. J Nutr. 2009;139:58-62

31. Fukino $Y$, Shimbo M, Aoki N, Okubo T, Iso H. Randomized controlled trial for an effect of green tea consumption on insulin resistance and inflammation markers. J Nutr Sci Vitaminol (Tokyo). 2005;51:335-42.

32. Fukino $Y$, Ikeda A, Maruyama K, Aoki N, Okubo T, Iso H. Randomized controlled trial for an effect of green tea-extract powder supplementation on glucose abnormalities. Eur J Clin Nutr. 2008;62:953-60.

33. Hill AM, Coates AM, Buckley JD, Ross R, Thielecke F, Howe PR. Can EGCG reduce abdominal fat in obese subjects? J Am Coll Nutr. 2007;26:3965-402S

34. Hsu CH, Tsai TH, Kao YH, Hwang KC, Tseng TY, Chou P. Effect of green tea extract on obese women: a randomized, double-blind, placebo-controlled clinical trial. Clin Nutr. 2008;27:363-70.

35. Hsu CH, Liao YL, Lin SC, Tsai TH, Huang CJ, Chou P. Does supplementation with green tea extract improve insulin resistance in obese type 2 diabetics? A randomized, double-blind, and placebo-controlled clinical trial. Altern Med Rev. 2011;16:157-63.

36. Kovacs EM, Lejeune MP, Nijs I, Westerterp-Plantenga MS. Effects of green tea on weight maintenance after body-weight loss. Br J Nutr. 2004;91:431-7.

37. Liu CY, Huang CJ, Huang LH, Chen IJ, Chiu JP, Hsu CH. Effects of green tea extract on insulin resistance and glucagon-like peptide 1 in patients with type 2 diabetes and lipid abnormalities: a randomized, double-blinded, and placebo-controlled trial. PLoS One. 2014;9:e91163.

38. Lu PH, Hsu CH. Does supplementation with green tea extract improve acne in post-adolescent women? A randomized, double-blind, and placebocontrolled clinical trial. Complement Ther Med. 2016;25:159-63.

39. Mielgo-Ayuso J, Barrenechea L, Alcorta P, Larrarte E, Margareto J, Labayen I. Effects of dietary supplementation with epigallocatechin-3-gallate on weight loss, energy homeostasis, cardiometabolic risk factors and liver function in obese women: randomised, double-blind, placebo-controlled clinical trial. Br J Nutr. 2014;111:1263-71

40. Mirzaei K, Hossein-Nezhad A, Karimi M, Hosseinzadeh-Attar MJ, Jafari N, Najmafshar A, Larijani B. Effect of green tea extract on bone turnover markers in type 2 diabetic patients; a double-blind, placebo-controlled clinical trial study. Daru. 2009;17(Suppl 1):38-44.

41. Miyazaki R, Kotani K, Ayabe M, Tsuzaki K, Shimada J, Sakane N, Takase H, Ichikawa H, Yonei Y, Ishii K. Minor effects of green tea catechin supplementation on cardiovascular risk markers in active older people: a randomized controlled trial. Geriatr Gerontol Int. 2013;13:622-9.

42. Nagao T, Hase T, Tokimitsu I. A green tea extract high in catechins reduces body fat and cardiovascular risks in humans. Obesity (Silver Spring). 2007;15: 1473-83.

43. Nagao T, Meguro S, Hase T, Otsuka K, Komikado M, Tokimitsu I, Yamamoto T, Yamamoto K. A catechin-rich beverage improves obesity and blood glucose control in patients with type 2 diabetes. Obesity (Silver Spring). 2009;17:310-7.

44. Ryu OH, Lee J, Lee KW, Kim HY, Seo JA, Kim SG, Kim NH, Baik SH, Choi DS, Choi KM. Effects of green tea consumption on inflammation, insulin resistance and pulse wave velocity in type 2 diabetes patients. Diabetes Res Clin Pract. 2006;71:356-8.

45. Sone T, Kuriyama S, Nakaya N, Hozawa A, Shimazu T, Nomura K, Rikimaru S, Tsuji I. Randomized controlled trial for an effect of catechin-enriched green tea consumption on adiponectin and cardiovascular disease risk factors. Food Nutr Res. 2011;55.

46. Suliburska J, Bogdanski P, Szulinska M, Stepien M, Pupek-Musialik D, Jablecka A. Effects of green tea supplementation on elements, total antioxidants, lipids, and glucose values in the serum of obese patients. Biol Trace Elem Res. 2012;149:315-22.

47. Tadayon M, Movahedi S, Abedi P, Syahpoosh A. Impact of green tea extract on serum lipid of postmenopausal women: a randomized controlled trial. J Tradit Complement Med. 2018;8:391-5.

48. Wu AH, Spicer D, Stanczyk FZ, Tseng CC, Yang CS, Pike MC. Effect of 2month controlled green tea intervention on lipoprotein cholesterol, glucose, and hormone levels in healthy postmenopausal women. Cancer Prev Res (Phila). 2012:5:393-402.

49. Zheng XX, Xu YL, Li SH, Hui R, Wu YJ, Huang XH. Effects of green tea catechins with or without caffeine on glycemic control in adults: a metaanalysis of randomized controlled trials. Am J Clin Nutr. 2013;97:750-62.

50. Kondo Y, Goto A, Noma H, Iso H, Hayashi K, Noda M. Effects of coffee and tea consumption on glucose metabolism: a systematic review and network meta-analysis. Nutrients. 2018;11(1):48.

51. Iso H, Date C, Wakai K, Fukui M, Tamakoshi A, Group JS. The relationship between green tea and total caffeine intake and risk for self-reported type 2 diabetes among Japanese adults. Ann Intern Med. 2006;144:554-62.

52. Waltner-Law ME, Wang XL, Law BK, Hall RK, Nawano M, Granner DK. Epigallocatechin gallate, a constituent of green tea, represses hepatic glucose production. J Biol Chem. 2002;277:34933-40.

53. Wolfram S, Raederstorff D, Preller M, Wang Y, Teixeira SR, Riegger C, Weber $P$. Epigallocatechin gallate supplementation alleviates diabetes in rodents. J Nutr. 2006;136:2512-8.

54. Mustata GT, Rosca M, Biemel KM, Reihl O, Smith MA, Viswanathan A, Strauch C, Du Y, Tang J, Kern TS, Lederer MO, Brownlee M, Weiss MF, Monnier VM. Paradoxical effects of green tea (Camellia sinensis) and antioxidant vitamins in diabetic rats: improved retinopathy and renal mitochondrial defects but deterioration of collagen matrix glycoxidation and cross-linking. Diabetes. 2005:54:517-26.

55. Giggey PP, Wendell CR, Zonderman AB, Waldstein SR. Greater coffee intake in men is associated with steeper age-related increases in blood pressure. Am J Hypertens. 2011;24:310-5.

56. Potter JF, Haigh RA, Harper GD, Fotherby M, Hurd S, Macdonald IA. Blood pressure, plasma catecholamine and renin responses to caffeine in elderly hypertensives. J Hum Hypertens. 1993;7:273-8.

57. Gasinska A, Gajewska D. Tea and coffee as the main sources of oxalate in diets of patients with kidney oxalate stones. Rocz Panstw Zakl Hig. 2007;58: $61-7$.

\section{Publisher's Note}

Springer Nature remains neutral with regard to jurisdictional claims in published maps and institutional affiliations.

\section{Ready to submit your research? Choose BMC and benefit from:}

- fast, convenient online submission

- thorough peer review by experienced researchers in your field

- rapid publication on acceptance

- support for research data, including large and complex data types

- gold Open Access which fosters wider collaboration and increased citations

- maximum visibility for your research: over $100 \mathrm{M}$ website views per year

At BMC, research is always in progress.

Learn more biomedcentral.com/submissions 